\title{
Ditadura Militar: mais do que algozes e vítimas. A perspectiva de Carlos Fico
}

Carlos Fico é Professor do Departamento e do Programa de PósGraduação em História da Universidade Federal do Rio de Janeiro (UFRJ) e Pesquisador do Conselho Nacional de Desenvolvimento Científico e Tecnológico (CNPq). Sua formação acadêmica ocorreu na própria UFRJ, na Universidade Federal Fluminense (Mestrado) e na Universidade de São Paulo (Doutorado em História Social e Pós-Doutorado). Atuou ainda na Universidade Federal de Ouro Preto (UFOP). Seu trabalho docente é voltado para ao ensino de Teoria e Metodologia da História e de História do Brasil Republicano. É um profícuo autor de artigos e livros que apresentam o resultado de suas investigações em temas como a ditadura militar no Brasil e na Argentina, historiografia brasileira, rebeliões populares no Brasil republicano e história política dos Estados Unidos durante a Guerra Fria. Criou o Centro Nacional de Referência Historiográfica na UFOP, juntamente com Ronald Polito. Foi "Cientista do Nosso Estado" da Fundação de Amparo à Pesquisa do Estado do Rio de Janeiro entre 2003 e 2006. Recebeu o Prêmio Sergio Buarque de Holanda de Ensaio Social da Biblioteca Nacional em 2008. Durante o Simpósio Nacional de História, ocorrido em Natal, dispôs-se a conceder esta entrevista para Tempo e Argumento, na qual expôs suas fundamentadas interpretações sobre as complexas relações entre a ditadura militar e a sociedade brasileira, bem como suas perspectivas sobre a História do Tempo Presente. Foi entrevistado por Silvia Maria Fávero Arend, Rafael Rosa Hagemeyer e Reinaldo Lindolfo Lohn, docentes do Programa de Pós-Graduação em História da UDESC. A entrevista foi transcrita pelo mestrando Hudson Campos Neves.

\section{Silvia Maria Fávero Arend}

Doutora em História pela Universidade Federal do Rio Grande do Sul. Professora da Universidade

do Estado de Santa Catarina. smfarend@gmail.com

\section{Rafael Rosa Hagemeyer}

Doutor em História pela Universidade Federal do Rio Grande do Sul. Professor da Universidade do Estado de Santa Catarina. rafael.hagemeyer@gmail.com

\section{Reinaldo Lindolfo Lohn}

Doutor em História pela Universidade Federal do Rio Grande do Sul. Professor da Universidade do Estado de Santa Catarina. reilohn@gmail.com

Entrevista concedida em: 24/07/2013

\section{Para citar esta entrevista:}

FICO, Carlos. Ditadura Militar: mais do que algozes e vítimas. A perspectiva de Carlos

Fico. [Entrevista realizada em 24 de julho, 2013]. Revista Tempo e Argumento, Florianópolis, v. 5, n.10, jul./dez. 2013. p. 464 - 483. Entrevistadores: Silvia Maria Fávero Arend, Rafael Rosa Hagemeyer e Reinaldo Lindolfo Lohn. 
Tempo e Argumento - Qual a sua compreensão sobre a História do Tempo Presente e a apropriação desta abordagem no Brasil?

Carlos Fico - É um conceito um pouco confuso. Não sabemos se a História do Tempo Presente é uma especialidade como as demais: História Antiga, Medieval, Moderna e Contemporânea, ou se é mais do que uma especialidade: uma periodização. A maioria dos historiadores que utiliza este conceito o faz como sendo uma periodização, com vista a determinados objetos marcados pelos eventos violentos do século XX. Então, é um conceito fugidio e confuso. Na França, durante muito tempo, essa tradição - que considero teoricamente frágil - discutiu um problema bastante irrelevante: qual o período abarcado pela História do Tempo Presente e qual geração vive este período? Acho uma discussão metodológica sem sentido porque não é um conceito consolidado. No caso do Brasil, muitos fazem essa discussão sobre quando começaria a nossa História do Tempo Presente: 1930? 1945? Uma tendência mais contemporânea discute se os regimes militares comporiam o mesmo rol de eventos que são tradicionalmente abordados pela História do Tempo Presente em outros países, sobretudo quanto à questão dos eventos traumáticos, como o Holocausto, os genocídios de Ruanda, as guerras na Bósnia e no Kosovo, o regime do Apartheid na África do Sul, o Nazismo, entre outros. Este é um tipo de discussão um pouco mais conceitual. Mas há uma inconsistência e generalização em torno desse conceito, com uma multiplicidade de abordagens e de temáticas. Não há sequer um consenso sobre ser essa noção uma periodização ou a definição de uma abordagem precisa.

Tempo e Argumento - A ditadura militar brasileira seria um marco definidor de nosso tempo presente, considerando os aspectos vinculados à violência política?

Carlos Fico - Do ponto de vista de uma periodização haverá em qualquer lugar uma História do Tempo Presente. Afinal, todo mundo, todo lugar tem uma História recente. Mas se nós pensarmos do ponto de vista da História do Tempo Presente como uma 
abordagem da História dos eventos traumáticos, muitos autores consideram que as ditaduras militares em geral, inclusive a brasileira, fariam parte desse rol de eventos violentos. Considero essa noção confusa para o caso do Brasil, pois há diferenças em relação ao caso argentino, internacionalmente emblemático pelo alcance da violência política. A última ditadura militar Argentina foi extremamente violenta: antes mesmo da ditadura ser imposta, a esquerda revolucionária fora extremamente violenta. O golpe foi recebido com certo alívio. Havia realmente uma conflagração muito grave, inclusive, prática da repressão clandestina anterior ao golpe. Refiro-me ao contexto anterior ao golpe de 1976 e posterior ao Cordobazo, ${ }^{1}$ que foi em 1969. A esquerda revolucionária fez uma opção desesperada pelo confronto, num processo crescente que chegou ao governo da Isabel Perón, ${ }^{2}$ um governo constitucional, mas muito frágil e sem sustentação, durante o qual foi deflagrada uma onda de repressão à luta armada, sobretudo na cidade de Tucumán. Depois do golpe militar de 1976, aqueles grupos clandestinos do tipo "comando de caça aos comunistas", 3 que atuavam antes do movimento militar, continuaram agindo e, mais do que isso: os militares passaram a fazer uma repressão brutal, mas a luta armada também não cedeu e, durante muito tempo, continuou com ações extremamente violentas. Quero dizer o seguinte: quando a literatura internacional se refere às ditaduras militares, na maioria das vezes os autores têm em mente o caso da Argentina, reconhecido pela violência brutal. Defendo que a noção da violência não serve para compreender o caso brasileiro. Muitos pensam que eu estaria dizendo que não houve violência durante a ditadura militar brasileira. É claro que houve violência na

\footnotetext{
${ }^{1}$ Rebelião popular ocorrida em 29 de Maio de 1969, na cidade de Córdoba, durante a ditadura imposta com um golpe militar em 1966, que derrubou o Presidente Arturo Illia, da Unión Cívica Radical. Nos desdobramentos do protesto, houve a tomada de edifícios públicos e instalações de grandes empresas industriais por parte dos manifestantes, em sua maioria jovens. A partir de então, houve o acirramento das lutas contra o regime, inclusive por meio de organizações clandestinas de luta armada.

${ }^{2}$ Isabel Perón ou Maria Estela Martínez, conhecida como Isabelita, nasceu em 1931. Casou, em 1960, com Juán Domingo Perón (1895-1974), principal personagem político argentino do século XX, que exerceu a Presidência do país entre 1946 e 1955 e de 1973 até sua morte, em 1974, quando Isabelita assumiu o poder. Seu governo foi derrubado pelo golpe militar de 24 de Março de 1976, comandado pelo General Jorge Rafael Videla (1925-2013).

${ }^{3}$ Organizações como o brasileiro Comando de Caça aos Comunistas (CCC), que atuou desde antes do golpe de 1964 e contava com integrantes oriundos do meio estudantil ,e policial, também tiveram existência na Argentina. Exemplo disso foi a Alianza Anticomunista Argentina ou Triple A, notoriamente conhecida por suas ações paramilitares e terroristas na década de 1970.
} 
ditadura militar brasileira. Todavia, o grau, o alcance, a abrangência da violência na Argentina, tanto da repressão quanto da luta armada, atingiu uma escala tão grande que afetou toda a sociedade. No Brasil, além da luta armada não ter sido expressiva, consistiu na guerrilha do Araguaia, ${ }^{4}$ que foi bastante pequena e nas ações armadas urbanas que eram também pouco expressivas e sem visibilidade, a repressão militar foi ocultada. $\mathrm{Na}$ Argentina foi visível. Os militares argentinos parece que faziam questão de dizer: "olha, nós vamos matar todo mundo". Diziam: "vamos matar todos os subversivos que forem necessários para a paz voltar à Argentina”. Então, era público e notório que havia uma conflagração violenta, havia campos de concentração. A esquerda também, quando patrocinava assassinatos de militares, publicava nos seus jornais exatamente como foi feita a execução daqueles homens. Logo, a sociedade estava tomada pela violência. Isso não tem nada a ver com o caso brasileiro, no qual houve censura e propaganda política, mas os militares não assumiam publicamente a violência da repressão e a luta armada foi relativamente inexpressiva. Acredito então que a noção de violência não serve para a análise do caso brasileiro, diferente de boa parte dos estudiosos que adotam noções como Sociedade do Medo ou Estado de Terror. Estas noções que, em suma, têm a ver com a categoria da violência, são inadequadas para o caso brasileiro.

Tempo e Argumento - Durante a ditadura, o Estado brasileiro não assumia a existência de torturas no país...

Carlos Fico - Mas Estado nenhum reconhece. Mesmo a Argentina não reconhecia. Havia no Brasil a defesa da tese dos “excessos” nos casos que vinham a público. Quando um ou outro caso vinha a público, ou era denunciado em espaços internacionais, os governos militares brasileiros respondiam que se tratava de "excessos". Evidentemente era uma tese falsa, porque os oficiais-generais tinham conhecimento dessa forma brutal de

\footnotetext{
${ }^{4}$ Movimento guerrilheiro comandado pelo Partido Comunista do Brasil (PCdoB), que organizou combatentes ao longo do Rio Araguaia, na altura dos municípios de Xambioá e Marabá, na Amazônia, a partir de 1967. As tropas do Exército passaram a combater a guerrilha em 1972, o que levaria ao extermínio progressivo do movimento até 1974.
} 
repressão que chegou ao Brasil, não só por meio de outros países, como a França e os Estados Unidos, mas também pela própria tradição de brutalidade da polícia brasileira. Então,„é claro que havia tortura, é claro que havia responsabilidade e conhecimento dos oficiais-generais brasileiros, mas afirmo que esta dinâmica oficialmente marcada pela violência - com cadáveres lançados à rua e campos de concentração e extermínio em massa - não aconteceu no Brasil. O que não significa dizer que não houve violência: não concordo com essa tese jocosamente intitulada de "ditabranda". ${ }^{5}$ Penso que isso é um equívoco, porque a sociedade brasileira foi vítima de uma espécie de violência muito ampla, sobretudo por causa dos serviços de informações. Mas não houve essa dinâmica marcada pela violência tout court do enfrentamento público. E, quando havia, os militares tentavam ocultar. Um dado interessante: quantifiquei as proibições da censura. Diariamente, um órgão da Polícia Federal, situado no Ministério da Justiça, o SIGAB, ${ }^{6}$ uma agência clandestina, enviava para os jornais os famosos bilhetinhos com ordens de proibição de assuntos. Metade dessas proibições, no período de auge da repressão, dizem respeito a enfrentamentos entre a repressão e a esquerda. Digamos, um grupo da esquerda revolucionária fez um assalto a banco no Rio de Janeiro e houve um confronto com a polícia no centro da cidade. Imediatamente esse órgão ordenava: "este assunto não pode ser noticiado". Isto significa que eles queriam evitar dar visibilidade à repressão, o que é o oposto exato do caso argentino, país no qual os militares deram toda a visibilidade à repressão durante a ditadura, com vistas a obter o apoio da sociedade para tais práticas, como de fato ocorreu. Pesquisas recentes de colegas argentinos mostram como a sociedade apoiou a repressão. Os estudos sobre a Argentina e o Brasil, como faço nos últimos anos, mostram que a comparação entre os dois casos é indevida. ${ }^{7}$

\footnotetext{
${ }^{5}$ Polêmica deflagrada por editorial do jornal Folha de São Paulo, do dia 17 de Fevereiro de 2009, que se referiu aos regimes autoritários sul-americanos das décadas de 1960 e 1970 como "ditabrandas", pois partiriam de "uma ruptura institucional" para depois preservarem, ou instituírem "formas controladas de disputa política e acesso à Justiça".

${ }^{6}$ Serviço de Informação do Gabinete (SICAB), órgão do Ministério da Justiça criado em 1970.

${ }^{7}$ Sobre a estrutura dos sistemas de repressão, espionagem e controle de informações, ver: FICO, Carlos. Como eles agiam: os subterrâneos da ditadura militar: espionagem e polícia política. Rio de Janeiro: Record, 2001.
} 
Tempo e Argumento - Qual sua posição nos debates em torno de denominações que vêm sendo empregadas para definir o regime imposto em 1964, como ditadura ou regime civil-militar e empresarial-militar?

Carlos Fico - Penso haver certo nominalismo nessa discussão, no sentido de acreditar que chegar a um nome,ou um conceito defina a natureza dos eventos. Há pouca densidade nessa discussão. Nas décadas de 1970 e 1980 houve também outro debate, que era muito difundido em torno do modelo teórico, o qual deveria ser adotado para analisar as ditaduras, ou os regimes militares. Tenho cautela em relação a isso, porque vejo o que chamo de nominalismo, que é essa pretensão, sobretudo entre os Cientistas Políticos, de que chegar a um nome, ou um modelo teórico signifique compreender a natureza dos processos. Penso que a natureza dos processos históricos é definida pela ação dos agentes e sujeitos históricos. Por isso, adoto a expressão "golpe civil-militar", mas para o período como um todo utilizo “ditadura militar”. Por que o golpe foi civil-militar? Por que houve apoio da sociedade? Não. Apoio houve, mas não é por isso que o golpe foi civilmilitar. Foi civil-militar por que os civis deram o golpe também. A natureza do evento golpe de Estado de 1964 é dada pela participação de sujeitos históricos, alguns militares e alguns civis. Os civis deram o golpe: Carlos Lacerda, ${ }^{8}$ Magalhães Pinto, ${ }^{9}$ governo dos Estados Unidos, enfim, uma série de agentes civis. No Congresso Nacional, o parlamentar Auro de Moura Andrade ${ }^{10}$ declarou a vacância do cargo de Presidente da República. Então, o golpe foi executado também por civis, mas o regime que se seguiu foi eminentemente militar. Logo depois do golpe, os próprios civis que participaram foram paulatinamente afastados, entre os quais Carlos Lacerda e Adhemar de Barros, ${ }^{11}$ além de outras lideranças civis. Tudo foi decidido pelos militares. Não havia nenhuma

\footnotetext{
${ }^{8}$ Em 1964, Carlos Frederico Werneck de Lacerda (1914-1977), integrante da União Democrática Nacional (UDN), era Governador da Guanabara, Unidade Federativa extinta no ano de 1975, quando de sua fusão com o Estado do Rio de Janeiro.

9 José de Magalhães Pinto (1909-1996), membro da UDN, era Governador de Minas Gerais em 1964.

${ }^{10}$ Auro Soares de Moura Andrade (1915-1982) pertencia aos quadros do Partido Social Democrático (PSD) e, na condição de Senador, era o Presidente do Congresso Nacional em 1964.

${ }^{11}$ Adhemar Pereira de Barros (1901-1969) era Governador de São Paulo quando da ocorrência do Golpe de 1964 .
} 
possibilidade de negociação. Os militares, a partir da prorrogação do mandato de Castelo Branco, ${ }^{12}$ assumiram definitivamente o poder institucional para legislar e fazer o que quisessem. Então, falar em ditadura civil-militar é uma cautela que me parece equivocada por essa razão. Embora compreenda que as pessoas queiram com isso chamar atenção para o apoio civil em alguns momentos, como durante o milagre econômico. Todavia, não é o apoio, em minha opinião, que define a natureza de um evento, mas a participação dos sujeitos históricos.

Tempo e Argumento - Outro assunto relevante diz respeito às relações entre a ditadura militar brasileira e os Estado Unidos...

Carlos Fico - Do meu ponto de vista, houve momentos muito distintos no relacionamento do governo norte-americano com os governos militares brasileiros. $\mathrm{O}$ golpe foi engendrado também pelo governo norte-americano. Desde 1963 havia uma estratégia definida para derrubar João Goulart. ${ }^{13}$ Essa estratégia também foi observada pelos golpistas brasileiros: Magalhães Pinto era o homem em contato com os Estados Unidos para a derrubada de Goulart. Houve a Operação Brother Sam, tudo isso que é bastante conhecido e mostra que os Estados Unidos apoiaram decididamente o golpe. Inclusive, para o primeiro governo militar, foi Castelo Branco o homem escolhido pelo governo norte-americano para realmente ficar no poder com a saída de Goulart. O padrão dos Estados Unidos para a derrubada de governos latino-americanos nunca se alterou. É sempre um padrão que considera não apenas a necessidade de afastamento de alguém, no nosso caso era o Goulart, mas eles sempre têm alguém preferido para colocar no lugar, que era o Castelo Branco. Esse padrão de intervenções norte-americanas aconteceu no Brasil. Portanto, esse primeiro governo foi sempre muito apoiado. Financeiramente, inclusive: o governo Castelo Branco recebeu muito suporte, mas,

\footnotetext{
${ }^{12}$ Humberto de Alencar Castelo Branco (1897-1967) foi o primeiro General-Presidente da ditadura militar. Tomou posse em 1964, quando foi também nomeado Marechal, e governou até 1967.

13 João Belchior Marques Goulart (1919-1976), membro do Partido Trabalhista Brasileiro (PTB), foi o Presidente da República deposto pelo golpe civil-militar de 1964.
} 
depois do Al-2 [Ato Institucional Número 2], em 1965, começou a haver resistência. Não se trata dos Estados Unidos como um todo, mas da Casa Branca, do Departamento de Estado, do Departamento de Defesa, do Congresso e da opinião pública. Havia confrontos entre o Departamento de Defesa, o Departamento de Estado e a Casa Branca. E no Congresso dos Estados Unidos repercutiram as denúncias de tortura e o caminho que o regime brasileiro tomou com o Al-2. A partir de então, o Secretário de Estado manifesta suas dúvidas: "não sei se a gente deveria ter apoiado esse negócio”. Quando vem o Al-5 [Ato Institucional Número 5], em 1968, há maiores complicações ainda no Congresso e na opinião pública, por causa das denúncias de tortura. O governo do Presidente norte-americano Richard Nixon ficou numa corda bamba. Havia seus próprios interesses em continuar apoiando uma ditadura, pois Nixon pouco se importava com democracia. Por outro lado, havia ainda o Congresso e a opinião pública. Muita gente não conhece isso, mas as primeiras ações nos Estados Unidos, da sociedade, da universidade, dos intelectuais e da Igreja protestante, em prol da defesa dos direitos humanos, provieram em grande medida de exilados brasileiros que conseguiram mobilizar algumas pessoas, ainda durante o governo Nixon. Começou um movimento de crítica e, quando o Presidente Médici $^{14}$ visitou Nixon, em 1971, esse grupo conseguiu espaço no New York Times, com alguma repercussão. Esse grupo foi base das mobilizações contra a tortura no Brasil e, depois que houve o golpe do Chile, em 1973, passou a assumir a questão chilena, assim como depois passaria à questão argentina. Essa base, na minha impressão e na avaliação de outros colegas, tem relação com a opção da campanha eleitoral de Jimmy Carter para a Presidência dos Estados Unidos em prol dos direitos humanos, em 1976. Esta trajetória mostra a diferença entre a sociedade norte-americana e o governo. Mesmo o governo apresentava todas essas clivagens. Depois do $\mathrm{Al}-5$ houve uma tensão no interior do governo norte-americano, ou seja, quanto a continuar apoiando o Brasil, porque não era possível largar um mercado de consumo e todos os compromissos comerciais e empresariais entre os dois países, mas atendendo às demandas do

\footnotetext{
${ }^{14}$ Emílio Garrastazu Médici (1905-1985) foi o terceiro General-Presidente da ditadura, entre 1969 e 1974.
} 
Congresso e da opinião pública, que viam com maus olhos o apoio dos Estados Unidos a um governo que praticava tortura.

Tempo e Argumento - A documentação norte-americana aponta para os momentos de tensão nas relações entre os Estados Unidos e a ditadura brasileira?

Carlos Fico - Trabalhei com essa documentação e publiquei um livro, O Grande Irmão, ${ }^{15}$ exatamente sobre isso, mostrando que não houve carta branca, a não ser no período de Castelo Branco. Depois as coisas degringolaram inteiramente. Houve momentos de grande tensão com Costa e Silva, ${ }^{16}$ que era um homem muito atabalhoado, muito doente, muito velho e relativamente nacionalista. Então, houve conflitos grandes. A documentação mostra um desgaste tremendo dos embaixadores norte-americanos com Costa e Silva, por conta também da negociação da compra de aviões de caça para a Força Aérea Brasileira, que não obteve êxito. Depois, com Ernesto Geisel, ${ }^{17}$ houve também todo um conflito em torno da questão do acordo nuclear com a Alemanha. Então, desde o Costa e Silva o período foi confuso. A lua- de-mel e apoio incondicional ocorreu na época do golpe e no governo de Castelo Branco. Isso por conta da presença do Embaixador dos Estados Unidos no Brasil, Lincoln Gordon, um amigo de Castelo Branco.

Tempo e Argumento - Em seu livro 'Reinventando o otimismo' ${ }^{\text {'18 }}$ o tema das relações entre ditadura e sociedade envolve os meios de comunicação. Até que ponto o estudo da propaganda e do controle dos grandes órgãos de comunicação, que apoiaram o golpe, é relevante para a compreensão do regime? Por outro lado, qual sua interpretação quanto a

\footnotetext{
${ }^{15}$ FICO, Carlos. O grande irmão: da operação Brother Sam aos anos de chumbo: o governo dos Estados Unidos e a ditadura militar brasileira. Rio de Janeiro: Civilização Brasileira, 2008.

${ }^{16}$ Artur da Costa e Silva (1899-1969), foi o sucessor de Castelo Branco e governou entre 1967 até 1969 , ano em que, convalescente, foi substituído no poder por uma Junta Militar.

${ }^{17}$ Ernesto Beckmann Geisel (1907-1996) foi o quarto General-Presidente da ditadura e governou entre 1974 e 1979.

${ }^{18}$ FICO, Carlos. Reinventando o otimismo: ditadura, propaganda e imaginário social no Brasil. Rio de Janeiro: Fundação Getúlio Vargas, 1997.
} 
narrativas mais recentes, como o documentário 'O dia que durou 21 anos', ${ }^{19}$ que pareceu ter renovado a visão de que houve uma meticulosa conspiração em 1964?

Carlos Fico - Não sei se é assim. Penso que o contexto do golpe e aquele a que se refere o livro, dez anos depois, são completamente diferentes. A propaganda começa timidamente em 1969, mas vai deslanchar mesmo na década de 1970. Durante o golpe, o papel da mídia foi muito importante. Não da televisão, que era inexpressiva naquele momento, mas a imprensa toda apoiou o golpe, foi mesmo essencial para a propagação da tese do comunismo de Goulart, de estarmos à beira do abismo e toda essa ideologia anticomunista que se propagou muito fortemente. Entretanto, quando a televisão passou a ter importância, com a inauguração da rede de micro-ondas para transmissão nacional, a propaganda teve um alcance maior e, portanto, impactou a sociedade de modo mais amplo e generalizadamente. Fiquei muito emocionado com o filme de Camilo Tavares, porque utiliza praticamente toda a documentação que levantei nos Estados Unidos. O documentário dramatiza uma situação, mas que é absolutamente verdadeira. Houve realmente uma conspiração. Hoje, sem a guerra fria, podemos considerar isso um pouco rocambolesco. Como é que o governo da principal potência mundial cogita invadir - Brasil, com mariners e um porta-aviões monumental? Isso é uma coisa tão aparentemente sem sentido, que é preciso fazer um esforço histórico muito grande para compreender porque foi possível naquele momento. Mas de fato houve essa conspiração, articulada com generais brasileiros de confiança do Castelo Branco. O Presidente João Goulart não resistiu porque foi avisado disso. Nós temos provas documentais de tudo isso. É algo tão chocante que mesmo tendo prova há essa sensação: “mas isso é muito conspiratório". Então, há provas documentais de tudo isso. Tudo o que está no filme é absolutamente correto e foi exatamente como aconteceu. Algumas coisas não estão no filme e, ainda assim, são muito graves, como o fato de que Magalhães Pinto seguiu o plano de contingência de 1963 dos Estados Unidos, declarando-se em estado de beligerância, tal como fora aconselhado pelo Departamento de Estado: um grande

\footnotetext{
${ }^{19} \mathrm{O}$ Dia que durou 21 anos. Documentário dirigido por Camilo Galli Tavares. 2013.
} 
Estado brasileiro deveria fazer isso para dar uma coloração constitucional à derrubada de Goulart. Então, é algo extremamente conspiratório. Claro, o golpe foi essencialmente brasileiro, mas tudo isso é verdade. No contexto seguinte, os militares estavam absolutamente senhores do poder e não enfrentavam nenhum risco, como supunham que fossem enfrentar. Eles acreditavam que haveria uma enorme resistência de Goulart, que não houve. Anos depois, na década de 1970, com o predomínio da TV, houve um "acordo de cavalheiros" para a cessão de vários minutos diários na televisão e os militares os usaram para fazer a propaganda que bem queriam. Este é um contexto diferente, quando estão totalmente senhores da situação.

Tempo e Argumento - Essa documentação norte-americana fornece algum indício sobre uma possível participação brasileira na chamada Operação Condor ${ }^{20}$ Considera crível a suposição de extermínio dos integrantes da Frente Ampla ${ }^{21}$

Carlos Fico - Nunca encontrei nenhum documento que confirmasse a participação do Brasil na "Operação Condor”. Ao contrário, encontrei documentos que mostram uma pretensão de superioridade dos generais brasileiros, pelos quais é muito difícil imaginar que se submetessem a um comando centralizado de oficiais latino-americanos. É outra coisa nominalista e que considero uma tremenda bobagem é essa discussão sobre a “Operação Condor”, porque os contatos entre os serviços de informações dos governos dos países latino-americanos, especialmente dos países do Cone Sul, existem desde antes da ditadura militar. Avolumaram-se, obviamente, durante os regimes militares, pois todos se sentiam muito afinados. E continuam até hoje: operações conjuntas de informações e de segurança entre os países latino-americanos são inclusive pautadas por convênios públicos, conhecidos e oficialmente assinados. Então, sempre houve operações, desde os

\footnotetext{
${ }^{20}$ Aliança de caráter político-militar, entre ditaduras sul-americanas (Brasil, Argentina, Chile, Bolívia, Paraguai e Uruguai), para a perseguição internacional a movimentos revolucionários e de resistência no Continente, ao longo da década de 1970.

${ }^{21}$ Grupo político lançado em 1966, por meio de manifesto publicado na imprensa, liderado por Carlos Lacerda e pelos ex-presidentes João Goulart e Juscelino Kubitscheck (1902-1976), com o objetivo de pressionar para a formação de um grande partido popular e em favor de reformas democráticas.
} 
anos de 1940, com troca de informações e também algumas ações de segurança, com a prisão de pessoas. Durante as ditaduras militares essas operações cresceram muito. Houve essa iniciativa chilena de querer uma coordenação à qual se deu esse nome, mas isso não se institucionalizou. O que houve foi a continuidade e crescimento das operações existentes. No caso do Brasil, nunca vi menção à palavra "Condor" sendo admitida pelos generais brasileiros. Houve inúmeras operações de informações com militares e policiais do Uruguai, da Argentina, do Chile, uma série de casos. Então, considero este também um problema de nominalismo. Como se quiséssemos chegar a uma grande coisa maquiavélica e articulada. Mas não era assim. Esses contatos, às vezes, eram feitos de maneira autônoma entre, por exemplo, o Dops ${ }^{22}$ do Rio Grande do Sul e a Agência de Segurança de Montevidéu, pois se conheciam e se entendiam. Então, essa grande rede é um pouco cinematográfica. Quanto ao caso da Frente Ampla, não tenho nenhum elemento empírico que comprove essa especulação. Nunca encontrei.

Tempo e Argumento - Ainda hoje há temas pouco abordados sobre o período, por exemplo: os movimentos operário e camponês foram atingidos ainda em 1964, embora persista a narrativa de que apenas depois de 1968 houve a ampliação de medidas repressivas, o que envolveu principalmente a classe média.

Carlos Fico - Desde 1964 houve repressão, tortura, prisões arbitrárias e, sobretudo, o desmantelamento do principal inimigo desses militares golpistas que eram os militares de esquerda, muitos se esqueceram disso. A principal preocupação foi fazer um saneamento das Forças Armadas e as primeiras punições visaram exatamente os militares de esquerda, vinculados ao Partido Trabalhista Brasileiro e Nacionalistas. Essa gente toda foi punida, afastada e posta na reserva. E também os sindicatos. Os sindicatos dos trabalhadores foram uma das primeiras vítimas dessa repressão inicial de 1964, porque naquele momento a classe média apoiava o golpe. Apoiava decididamente o golpe. Não havia porque a classe média ser atingida pela repressão, pois apoiava o golpe. Isso

\footnotetext{
${ }^{22}$ Departamento de Ordem Pública e Social, vinculado aos Governos Estaduais e voltado para a repressão política durante a ditadura militar.
} 
começou a degringolar com o plano de saneamento financeiro imposto pelos Estados Unidos, adotado calorosamente pelo Castelo Branco e seus ministros, Roberto Campos ${ }^{23}$ e outros, porque gerou arrocho salarial e carestia de vida. Em seu final, o governo Castelo Branco foi muito impopular e o presidente era visto como ditador. As pessoas viam a candidatura de Costa e Silva com a esperança de que fosse um bom homem, mais humano. Em algumas declarações, disse que o controle da economia não poderia penalizar o homem. Vejam como são as coisas: Costa e Silva, naquele momento, foi visto como esperança e Castelo Branco como ditador, e foi exatamente assim que aconteceu. O fim do governo Castelo Branco foi de extrema carestia, o que seria inclusive a base do milagre econômico, que Costa e Silva aproveitou e Médici aproveitaria mais ainda. Esse momento foi de muita insatisfação: aquelas senhoras que participaram das marchas ${ }^{24}$ começaram a reclamar. Os estudantes também estavam insatisfeitos porque houve muita censura ao teatro e a livros, no final do governo Castelo Branco, além de cerceamento das entidades estudantis. A Igreja, que apoiou decididamente o golpe, também começou a ficar insatisfeita porque na transição entre Castelo Branco e Costa e Silva houve prisão de clérigos. Então, quem tinha apoiado começou a ficar insatisfeito. A partir daí, portanto, muitos passaram de apoiadores a vítimas da repressão. Publiquei um artigo sobre esse movimento ondulatório da classe média em relação à ditadura, ${ }^{25}$ dependente da economia, como até hoje a classe média oscila em relação à economia.

Tempo e Argumento - Quais seriam as perspectivas da produção historiográfica brasileira em relação ao tema da ditadura?

Carlos Fico - Há algumas perspectivas importantes. Uma delas diz respeito à documentação sigilosa que atualmente está disponível, depois de muitos anos de luta, graças à Lei de Acesso à Informação. É uma documentação monumental, da qual não se

\footnotetext{
${ }^{23}$ Roberto de Oliveira Campos (1917-2001) era o Ministro do Planejamento do Governo Castelo Branco.

${ }^{24}$ Marchas da Família com Deus pela Liberdade, ocorridas às vésperas e, logo após, o golpe de 1964.

${ }^{25}$ FICO, Carlos. La "classe média" brésilienne face au régime militaire: du soutien à la désaffection (19641985). In: Vingtième Siècle. Revue d'histoire, 2010, n 105, p. 155-168.
} 
conhece, acredito, nem dez por cento. Então, essa documentação vai trazer muitas informações novas e acho que isso será, nos próximos anos, a marca. Outra marca também tem a ver com essa visão regional: algumas pesquisas muito interessantes mostrando como esses processos ocorreram em diversos lugares diferentes. Até hoje temos uma História da ditadura muito centrada em Rio de Janeiro e São Paulo, mas estão ocorrendo mudanças graças aos programas de pós-graduação. Existem algumas questões teóricas. Uma delas é uma prefiguração discursiva de "mocinho e bandido". A história da ditadura militar seria uma história da repressão de militares enlouquecidos que, de repente, teriam decidido ser torturadores, contra uma sociedade vitimizada. Essa é uma visão totalmente simplista, que não se sustenta de jeito nenhum, mas ainda inspira, como uma prefiguração discursiva, boa parte das pesquisas. Poucos pesquisadores têm a cautela de dizer que houve apoio da sociedade, que um regime de 21 anos não se sustenta sem o apoio da sociedade, que os militares tomaram essa decisão não porque fossem loucos, mas porque houve apoio da sociedade ao golpe. O golpe de 1964 foi o evento chave da história recente do país, porque mostra essa tradição de autoritarismo brasileiro que existe até hoje e esse apoio da sociedade às medidas autoritárias. Acredito que a desmontagem dessa prefiguração discursiva é importante. Até porque nós temos uma memória muito disputada sobre esses eventos: a militância dos Direitos Humanos busca fazer exatamente a equivalência a que me referi antes, no sentido de que a ditadura militar brasileira devesse ser lida conforme a categoria, ou a noção da violência. Então, essa militância erigiu e transformou em evento emblemático da História da ditadura o confronto entre a repressão e a esquerda, sendo esta armada ou não. E, evidentemente, não foi este o evento emblemático da História da ditadura brasileira, ao contrário do que foi, por exemplo, na Argentina. A memória que se constituiu na Argentina é uma memória marcada pelo trauma diante dessa violência brutal. Mas a memória da sociedade brasileira não é uma memória marcada por esse trauma, porque este não foi o fenômeno mais importante. O fenômeno mais importante, me parece, é o da frustração, uma categoria para compreender, sobretudo, a transição brasileira. A frustração devido à ausência de uma ruptura. Como a ditadura acabou? O chefe do PDS, ${ }^{26}$

\footnotetext{
${ }^{26}$ Partido Democrático Social (PDS), formado como sucedâneo da Aliança Renovadora Nacional (ARENA),
} 
o principal líder político da ditadura, foi quem assumiu o primeiro governo civil. Vejam que no caso da Argentina, houve uma guerra e um julgamento das Juntas Militares, logo no primeiro governo civil de Raúl Alfonsín, ${ }^{27}$ os generais-presidentes foram presos, julgados e punidos. Aqui não houve nada disso. Então, instalou-se uma frustração na esquerda, com a ausência de ruptura e a impunidade. Acredito que categoria frustração é muito mais importante no caso brasileiro do que a noção da violência. De algum modo, explica porque que só agora temos algumas medidas de Justiça de Transição. Demorou, passaram-se dez anos, desde 1985 até 1995, quando foi criada a primeira comissão sobre mortos e desaparecidos no Brasil. ${ }^{28}$ Então, avolumou-se uma frustração na esquerda que só teve alguma vazão com os primeiros governos de presidentes que, de alguma maneira, contestaram a ditadura, Fernando Henrique Cardoso, Luís Inácio Lula da Silva e a presidente Dilma Rousseff, com a Comissão Nacional da Verdade. ${ }^{29}$ Essas medidas de Justiça de Transição demoraram muito por conta dessa característica peculiar da ditadura brasileira.

Tempo e Argumento - Uma das questões que enfrentamos está relacionada à ética na pesquisa dos documentos chamados sensíveis. Como lidar com esse material que pode dizer respeito a dimensões muito sensíveis de pessoas que sofreram violências ou perseguições?

Carlos Fico - Isso é complexo porque precisamos de muita transparência em relação a esses assuntos. Por outro lado, é preciso resguardar as pessoas, sobretudo as que ainda estão vivas. Tenho muitas experiências pessoais dramáticas em relação a isso: encontrar

após o retorno do pluripartidarismo, em 1979. A ARENA fora criada em 1965, quando da imposição do bipartidarismo ao país, para abrigar os políticos civis que apoiaram a ditadura. Seu adversário era o Movimento Democrático Brasileiro (MDB), que se constituiu na oposição consentida pelo regime e seria a base para a formação do Partido do Movimento de Democrático Brasileiro (PMDB), na mesma época em que foi articulada a legenda do PDS.

${ }^{27}$ Raúl Ricardo Alfonsín (1927-2009), da Unión Cívica Radical, foi o primeiro Presidente da Argentina após a democratização do país e exerceu seu mandato entre 1983 e 1989.

${ }^{28}$ Comissão Especial sobre Mortos e Desaparecidos, criada após a Lei 9.410, de 1995, conhecida como Lei dos Desaparecidos.

${ }^{29}$ Instalada oficialmente em 16 de Maio de 2012. 
na documentação situações muito delicadas, muito pessoais, que suscitam dúvidas que não são relativas apenas a divulgar, ou não alguma informação por meio de livros ou artigos. É mais grave ainda. É a dúvida ética quanto a ser, ou não ser adequado avisar a pessoa. Recordo do caso de um funcionário de carreira da Petrobrás que foi cogitado para assumir uma diretoria importante na empresa. Esse funcionário, assim como qualquer outro que era cogitado para nomeações importantes, foi fichado pelo órgão de informações que atuava na Petrobrás. E o agente de informações fez o seguinte relato: “esse funcionário é um notório comunista, subversivo e frequenta reuniões no partido". Essa informação foi para o presidente da Petrobrás que desistiu da nomeação. Os agentes de informações tinham esse poder de intimidar com esses papéis. E o que aconteceu? Este homem era um homônimo. Este infeliz da Petrobrás era completamente apolítico, apartidário, jamais foi de esquerda, era até bastante conservador. Mas era homônimo de um efetivo comunista. Assim como essa, houve muitas situações de pessoas que foram prejudicadas e sequer sabem. Então, demorei muitos anos até dar a notícia para esse cidadão: ele ficou absolutamente chocado. Não sei se fiz bem em dar essa notícia. Essa questão ética é também uma questão política muito importante. Para Comissão Nacional da Verdade, conforme o senso comum, vítimas da ditadura são as pessoas que foram presas e torturadas. Nós temos que fazer um esforço, na historiografia pelo menos, pois a Comissão Nacional da Verdade é um fracasso, de inserir no rol das vítimas essas pessoas comuns. Muitas delas, como exemplifiquei, nem sabem que foram prejudicadas na carreira, ou isso não significa ser vítima? Vítima é só quem foi preso e torturado? A militância dos Direitos Humanos constituiu uma memória prevalecente que erigiu como fato emblemático o fenômeno da violência, da repressão, que no caso do Brasil é inadequado. E isso tem impedido a inclusão no rol das vítimas de pessoas comuns. Como a Comissão Nacional da Verdade é pautada pela militância dos Direitos Humanos, como supunha que fosse e, por isso, recusei-me a participar, não incorpora no rol das vítimas grande parcela da sociedade. O que aconteceria se incorporasse? Há uma enorme apatia e desinteresse das pessoas por este assunto no Brasil, pois ninguém sabe o que é a Comissão Nacional da Verdade, só nós e a imprensa. Aconteceria que pessoas comuns se interessariam por este passado que afetou o seu pai, 
ou a sua mãe? Não foi só aquele pai militante da esquerda, mas também o que era um funcionário público? Essa documentação está em Brasília à espera de pesquisa: os dossiês das pessoas comuns que foram atingidas pela ditadura militar.

Tempo e Argumento - Havia as Divisões e Assessorias de Segurança e Informações nos órgãos públicos...

Carlos Fico - Em toda empresa estatal, em toda autarquia, em toda fundação, em todo o lugar que houvesse possibilidade, havia um órgão de informações. Esses órgãos de informações faziam esses dossiês, que são centenas, muitos dos quais já estão no Arquivo Nacional, inéditos. Fiz muita força para que a Comissão Nacional da Verdade se voltasse também para a pesquisa desses documentos, mas não houve interesse. Oferecemos bolsas da Capes para que pesquisadores do Brasil inteiro se candidatassem e fossem pesquisar esse material em Brasília, mas não houve interesse. Então, até hoje no Brasil as vítimas são apenas as que foram atingidas pela repressão tout court, no sentido da tortura, da repressão e do desaparecimento. Foram vítimas, sim. Mas há outras. Então, esta é necessidade a que me referi de desconstrução de uma prefiguração discursiva, que é um enredo pronto. O bem e o mal: o militar malvado, a sociedade boazinha e a luta armada contra a repressão. Isso é prejudicial. É prejudicial porque a história do Brasil entre 1964 e 1985 não se reduz à História da ditadura militar.

Tempo e Argumento - Há autores que se referem a uma zona cinzenta, na qual há um raio de atitudes que não se reduzem apenas a apoiar, ou a opor-se, mas também envolve intimidação, cooptação ou colaboração direta de pessoas que não têm interesse que isso seja levantado. Como lidar com isso na pesquisa?

Carlos Fico - São coisas diferentes. Houve, por exemplo, casos de pessoas que foram presas e tiveram a oportunidade de serem libertadas se gravassem um depoimento para a televisão dizendo-se arrependidas. Era uma armação dos órgãos de contrapropaganda: 
"olha, se você quiser, nós liberamos você, deixamos você ir embora, sai da prisão desde que grave um depoimento dizendo estar arrependido". Isso aconteceu. Em alguns casos essas pessoas viveram a partir daí um drama tremendo, foram renegadas pela esquerda. Muitas viveram problemas psicológicos gravíssimos e saíram do país. Essa é uma categoria muito complexa para analisar e não sei como chamar esse tipo de caso. A pessoa, no desespero de lutar pela sua vida, concorda em se dizer arrependida, não sabemos se convicta disso. Outra coisa, são os que eram os colaboradores dos órgãos de informações por qualquer razão. Até por dinheiro, pois muita gente recebia pagamentos: era um sistema enorme que precisava de agentes não públicos. Pessoas eram contratadas porque tinham, digamos, afinidade política com o regime, ou porque queriam ganhar um trocado. Há muitos casos de funcionários de universidades que foram informantes dos órgãos de informações por dinheiro. Esses eram agentes da repressão também. Então, não há dúvida quanto a isso. Ocorre que essa noção de área cinzenta do Pierre Laborie $^{30}$ é um pouco óbvia, em minha opinião. Mas é útil. Um caso que sempre tenho citado é o de Silvaldo Leung Vieira, o fotógrafo do cadáver de Vladimir Herzog no DOI-CODI. ${ }^{31} \mathrm{O}$ fotógrafo havia entrado poucas semanas antes para a Polícia Civil de São Paulo. Passou em um concurso e estava em um curso de fotografia oferecido na Universidade de São Paulo para aquelas fotos com data, quando uma pessoa é presa e fichada, além de outros serviços. Foi convocado pelos militares do DOI-CODI para uma missão especial. Chegou e viu que tinha que fotografar o cadáver de Herzog, para aquela história de forjar um suicídio. Ele era um garoto novo, fez aquela foto e ficou muito nervoso. Continuou a realizar o curso. Depois foi chamado de novo para fazer a foto de Manoel Fiel Filho. ${ }^{32}$ Viu que eram coisas muito esquisitas e, com o passar dos meses, foi chamado para outros serviços desse quilate, até que não aguentou mais. Creio que

\footnotetext{
${ }^{30}$ LABORIE, Pierre. Les Français des années troubles. De la guerre d' Espagne à la Libération. Paris, Seuil, 2003.

${ }^{31}$ O jornalista Vladimir Herzog (1937-1975), ou Vlado, foi assassinado nas dependências do Destacamento de Operações de Informações - Centro de Operações de Defesa Interna (DOI-CODI) em São Paulo, órgão do Exército criado para a repressão política. O órgão repressivo divulgou a causa da morte como suicídio por enforcamento, o que seria desmentido.

32 Manoel Fiel Filho (1927-1976) era um operário que fazia parte da base do Partido Comunista Brasileiro $(P C B)$. Foi assassinado sob torturas no DOI-CODI.
} 
durante as férias, ou algo assim, ele fugiu do Brasil. Foi para os Estados Unidos e lá ficou, até hoje. Foi descoberto pela Folha de São Paulo. Foi um agente da repressão ou uma vítima da ditadura? É muito fácil falar que ele foi agente da repressão porque ele era da Polícia Civil e fotografou o cadáver de Herzog. Mas será que ele foi, de alguma maneira, vítima das circunstâncias? Fugiu, viveu no exílio e permaneceu clandestino por algum tempo. Não sei como se arranjou para legalizar sua situação nos Estados Unidos. Isso mostra o quanto é difícil você usar essas categorias simplistas para estudar fenômenos complexos. Sempre digo que a condenação do mal é um truísmo: você é historiador e faz um esforço analítico tremendo para chegar à conclusão de que o mal é mal. Isso é o óbvio. Então, condenar o mal, qualquer pessoa deve fazê-lo, claro. Entretanto, devemos ir um pouco além e mostrar esse tipo de complexidade. Assim como o caso do fotógrafo, houve muitos outros. Esses órgãos de informações, o próprio SNI, ${ }^{33}$ contratavam muita gente. O SNI chegou a ter dois mil funcionários. Quando alguém estava sendo torturado por um agente da repressão, as informações extraídas dessa pessoa, naquela agonia, eram analisadas por um agente de informações. As confissões eram datilografadas ali mesmo por um funcionário a serviço do DOI-CODI. Como é possível entender essa pessoa? Havia esse universo de pessoas em torno dessa atividade da repressão e o que há de mais dramático na história dos eventos violentos, dos eventos traumáticos, é que os algozes, os agentes da repressão, são pessoas comuns. Então, é preciso também levar isso em consideração. Quer dizer, a repressão não foi feita só por um bando de militares tresloucados que saíram dando choque elétrico em todo mundo. Houve uma estrutura que permeou a sociedade e que envolveu civis. O fotógrafo teria sido agente da repressão? Seria vítima, ou esse funcionário, que devia trabalhar no INPS, ${ }^{34}$ foi requisitado e ficou lá, diante daquela situação? E ele poderia fazer o quê? Perder o emprego? Ele era um agente da repressão? Ele era o quê? Então, são fenômenos muito mais complexos do que essa prefiguração discursiva do bem e do mal.

\footnotetext{
33 Serviço Nacional de Informações (SNI), que foi a peça principal do Sistema Nacional de Informações (SISNI) durante a ditadura, funcionou de 1964 até 1990.

34 Instituto Nacional de Previdência Social (INPS), criado em 1966 pela fusão de Institutos de Aposentadorias e Pensões.
} 
